\section{Deradicalization of former terrorists in East Java, Indonesia: the commitment to Islamic religious education}

\author{
Desradicalización de antiguos terroristas en Java Oriental, Indonesia: el compromiso con \\ la educación religiosa islámica
}

Ishomuddin Ishomuddin; Ali Fauzi; Syamsul Arifin; Abdul Haris

\begin{abstract}
Terrorists in Indonesia arise due to the degree of subjectivity of the interpretation of Islam in religious groups. To this is added the problem of interaction with foreign cultures that have other viewpoints on the teachings of Islam. This study aims to describe the role of the Foundation Education of "Peace Circle" in conducting moderation education for former terrorists. This research uses a social definition paradigm, a qualitative approach, with a phenomenological type of research. With phenomenological analysis, the results are as follows: The presence of Peace Circle Foundation (PCF) is interpreted and felt by former convicts as a place of refuge and hope for spiritual and non-spiritual support for the future life. The insight and understanding of Islam provided are overly broad and thorough, and the skills and training are very real and functional. As a result, the subject is no longer radical and angry with the government. All subjects were happy with PCF's presence to handle the healing and help of ex-terrorist convicts who had carried out disengagement.
\end{abstract}

Keywords: Education Model; Terrorist; Deradicalization Fundamental; Peace Circle Foundation

\section{RESUMEN}

Los terroristas en Indonesia surgen debido al grado de subjetividad de la interpretación del islam en los grupos religiosos. A esto se añade el problema de la interacción con culturas extranjeras que tienen otros puntos de vista sobre las enseñanzas del islam. Este estudio pretende describir el papel de la Fundación de Educación del "Círculo de la Paz" en la conducción de la educación para la moderación de los antiguos terroristas. Esta investigación utiliza un paradigma de definición social, un enfoque cualitativo, con una investigación de tipo fenomenológico. Con el análisis fenomenológico, los resultados son los siguientes: La presencia de la Fundación Círculo de Paz (PCF) es interpretada y sentida por los ex convictos como un lugar de refugio y esperanza de apoyo espiritual y no espiritual para la vida futura. La visión y la comprensión del islam que se ofrece son muy amplias y profundas, y las habilidades y la formación son muy reales y funcionales. Como resultado, el sujeto ya no es radical ni está enfadado con el gobierno. Todos los sujetos estaban contentos con la presencia del PCF para gestionar la curación y la ayuda de los ex convictos terroristas que habían llevado a cabo la desvinculación.

Palabras clave: Modelo de Educación; Terrorista; Fundamento de la desradicalización; Fundación Círculo de Paz
RELIGACIÓN

REVISTA DE CIENCIAS SOCIALES Y HUMANIDADES JOURNAL OF SOCIAL SCIENCES AND HUMANITIES REVISTA DE CENCIAS SOCIAIS E HUMANAS

\section{ARTICLE INFORMATION:}

https://doi.org/10.46652/rgn.v6i30.836

ISSN $2477-9083$

Vol. 6 No. 30, 2021. e210836

Quito, Ecuador

Submitted: August 24, 2021

Accepted: October 10, 2021

Published: November 18, 2021

Continuous Publication

South-South Section | Peer Reviewed

\section{(c) (i) $\odot$}

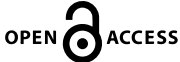

\section{AUTHORS:}

Ishomuddin Ishomuddin Muhammadiyah University of Malang Indonesia | ummishom@gmail.com

Ali Fauzi

Muhammadiyah University of Malang Indonesia | manzi2009@yahoo.com

Syamsul Arifin

Muhammadiyah University of Malang - Indonesia | syamsul.frahman67@ gmail.com

\section{Abdul Haris}

Muhammadiyah University of Malang Indonesia | haris@umm.ac.id

\section{CONFLICT OF INTEREST}

No potential conflict of interest is reported by the authors.

FUNDING

No financial assistance from parties outside this article.

ACKNOWLEDGMENTS

Thank for the director of Peace Circle Foundation (PCF), Lamongan, East Java, Indonesia. Thanks for rector of University of Muhammadiyah, Malang.

\section{ENTIDAD EDITORA}




\section{Introduction}

The events of September 11th, 2001 destroyed one of the symbols of America's economic superiority, the World Trade Center (WTC) building, and one of the symbols of the world's military superiority, the Pentagon building. Regardless of who the real perpetrators of this terrible action were, the events of September 11, in 2001 still leave an interesting discourse in the Islamic world, namely, the discourse on terrorism from the Islamic point of view. According to Budisusilo (2001), the opinion that was vociferated by many groups, both Muslim and non-Muslim, is a condemnation of acts of "terrorism," including the actions of September 11th, 2001, in New York and Washington that killed thousands of people. This action is a cursed act hich was engineered by the Israeli Intelligence Service, the Mossad, or engineered by America itself. Therefore, they - the Muslims - have declared that it is proven that Osama bin Laden is involved in the action. Osama himself, as published in the Rakyat Merdeka newspaper (September 29, 2001), stated that the possible perpetrators of the September 11 actions were armed militant groups from America itself.

Thereafter, many, even among Muslims, engage in condemnation of so-called "terrorism," without making an in-depth study of the term which has been designed for its meaning and purpose by the West, especially the United States. Perhaps Muslims are already in a cornered position because the word "terrorist" has been perceived by the public as an "evil act," like the words “fundamentalist Islam," "militant Islam," radical Islam, etc. Moreover, US President George Walker Bush, while addressing the US Congress on September 20, 2001, gave an ultimatum to all the mankind on this earth: "Every nation in every region must now make a choice: Either you are with us, or you are with the terrorists. From this day forward, any nation that continues to harbor or support terrorism will be considered by the United States to be a hostile regime."

Freely translated, every nation now has two choices; join the United States of America or stand with the terrorists. In that sense, nations that protect terrorism will be put under the category of "evil government", being a threat to the rulers of the world at that time. The USA has won the war of opinion by imposing the term "terrorism" in the sense of "crimes committed by America's enemies".

According to Husaini (2001), these global conditions have attracted countries with Muslim populations to carry out various reactions. For example, in Indonesia, the Bali I and Bali II bombings could not be separated from the reaction to these global events carried out by the "jihadists" or popularly called "terrorists" and a series of other incidents that followed. To this day, the local government continues to monitor and comb locations or cities suspected of having terrorist bases. In fact, according to Arifin and Hasnan (2013), radicalism and terrorism have appeared lately. Various mass and electronic media often report on terrorists. Meanwhile, radicalism is not only carried out by old groups such as the Indonesian Mujahideen Council (MMI), Islamic Defenders Front (FPI), Jamaah Islamiyyah (JI) and Lascar Jihad but brutal ideas and violence have spread in many Muslim communities in the archipelago.

For the past ten years, the treatment of terrorists has involved, in addition to operations carried out by police officers, also education for deradicalization, striving in all educational institutions from early childhood level to universities, even when Vice President Ma'ruf Amin ordered the National Police to monitor and listen to the sermons of preachers in mosques, especially during Friday prayers. All activities, especially religious ones, were instructed to be deradicalized. Deradicalization has become a "popular" vocabulary as well as a controversy during the reign of President Joko Widodo since the first term. 
One of the foundations is dedicated to training the families of former terrorists and the place where they return to before socializing with the community at large is the Peace Circle Foundation in the village of Tenggulun, Solokuro, Lamongan regency. This foundation was founded by former terrorists. This foundation is one of those dedicated to the Control Flow Integrity (CFI) with the aim of changing the mindset of ex-terrorist and ex-terrorist convicts to a friendly and nonconfrontational form of Islam and keeping them away from destructive attitudes. The founder of this foundation brought together several ex-combatants such as Anis Yusuf, Osama Bin Laden's former group, Iqbal Hussein Thoyib, a bomb planner for the National Police Headquarters, and others. Currently, the foundation has 60 trustees throughout Indonesia.

Among the efforts, the Private Foundation has undertaken are holding non-formal education, workshops on strengthening the economic skills of young people through journalism training. The foundation also organizes training courses for the children of ex-convicts through their participation.

The most important effort made by the "Circle of Peace" Educational Foundation in the field of non-formal education is to bring the understanding of Islam back to the understanding of mainstream Islam, i.e., Islam as understood by Muhammadiyah, Nahdlatul Ulama, Persis in general. This effort received a positive response from both the community and the government, especially the National Counter-Terrorism Agency (BNPT), as it was considered quite successful. This research was conducted to find out how the non-formal education of the "Peace Circle" Foundation de-radicalized the Islamic understanding of ex-terrorists. How has the terrorist's experience in understanding radical fundamental Islamic teachings led them to become terrorist actors? How do ex-terrorists view other groups and mainstream Islam in Indonesia? It is interesting to study the phenomenon of the Peace Circle Foundation as one of the efforts to overcome and prevent radical fundamentalism.

Based on the description of the background of the problem above, it can be formulated as follows: What is the model of the "Peace Ring" educational foundation in conducting education for former terrorists? Based on the above formulation, the objectives of this research are: To describe the Peace Circle Foundation education in conducting Moderatin education for former terrorists in Lamongan, East Java.

\section{Literature Review}

What exactly is an act of terrorism? The word terror, in Arabic, is called irhab. While the word alirhab is translated as 'intimidation, threat', the Oxford Advand Learner's Dictionary of Current English defines terror as great fear; terrorism is defined as the use of violence and intimidation; and terrorism is defined as supporter of or participant in terrorism. According to Jainuri (2006), the terms terror and terrorism have become immensely popular social science language in the 1990 s and early 2000 s as a form of religious group. Terrorism, though, is not a new term. Acts of terror have appeared throughout human history.

In the history of the Islamic Movement of the late 18th century, for example, the Wahhabi movement in the Arabian Peninsula, led by Muhammad bin Abduh Wahab (1703-1792) and Sayyid Ahmad Syahid (1786-1831), is recognized. This movement (along with other figures such as Hasan al-Banna, Sayyid Qutb, Abul A'la Al-Maududi, Muhammad Abduh, Jamaluddin Al-Afghani, Rasyid Rida, and several other names in various parts of the world) was triggered by the life of the Muslim community, which was considered to have deviated in many respects from Islamic principles. The Islamic society at that time was penetrated by the notion that comes from the 
non-Islamic. The values of the Islamic community have been practicing customs and doing habits that are far from the spirit of the teachings contained in the authentic sources of the Qur'an and Sunnah. Among the deviant beliefs in daily life is that the Ulama have been made and become direct intermediaries of God to attend to the needs of the community. The graves of the Ulama or those who are considered guardians of Allah become a place to ask for something on the part of the community members in solving their life problems (Elshahed, 1992).

The looseness of Islamic society in holding Islamic teachings in daily life to the extent of these deviations cannot be separated from the weakening of the government of the kings who ruled in previous eras, both under the Ottoman, Safavid, and Mughal kingdoms (born around the 16th century), faded at the end of the 18th century), as the successor to the glory of the two previous dynasties, namely the Umayyads and the Abbasids.

All these traditions or cultures are protested and strongly opposed by this movement. The religious actions that are actualized in the Wahabiyyah movement articulate their position orally, but also with actions in the implementation of this belief that are also carried out militantly, for example, destroying and smashing the tombstones of the graves of the Ulama, because the pilgrimage to the grave is considered an un-Islamic tradition that is a polytheistic reflection. The graves of scholars are sacred and are used as a place of petition or as an intermediary before Allah to ask for something. The predicate "musyrik" is given to a religious act that has a negative value or is the most disobedient to Allah.

The externalization of these Wahabiyyah figures, in addition to being able to effectively eradicate deviations from Islamic teachings that had legitimized the authority of the Ulama at that time, was finally able to establish cooperation with local authorities, even being able to obtain the support of military forces to criticize and protest against deviant traditions. The militant externalization and internalization efforts of the leaders of the Wahabiyyah movement succeeded in reaching the level of the objectification process in the form of spreading its Islamic conception throughout the Arab territory. The thought and interpretation of this movement in the understanding and practice of Islam eventually became a formal reference of the Kingdom of Saudi Arabia (Tehranian, 1993).

\section{Methodology}

In accordance with the objectives and the unit of analysis, this study used a social definition (social action) paradigm (Ritzer, 2003), (Cerswell, 1998). The research uses a qualitative approach (Guba, 1978). The type of research is of the phenomenological type, while the methods of data collection are observation, in-depth interviews, and documentation. The place of this research is the Education Foundation which is located in Solokuro Village, Lamongan Regency, Indonesia. Solokuro was the starting place of the terrorist base that carried out the Bali I and Bali II bombings and a series of bombings elsewhere. Now, at that location, non-formal educational institutions have also been established to conduct deradicalization of former terrorists from Lamongan Regency or other cities.

The research subjects were selected through purposive techniques, i.e., with certain criteria. The researcher examined the process of deradicalization education in the field and conducted interviews to obtain data related to the experience of understanding religion and observing behaviors in or out of activities. The criteria for the subject are (1) Subjects suspected/decided to be involved in committing minor acts of terror (2) Subjects suspected/decided to be involved in committing serious acts of terror (3), and all subjects who have been released from prison who have joined non-formal education at the Circle of Peace Foundation. 
The data analysis technique used in this research is phenomenological analysis, here there are several characteristics that are specifically found in all phenomenological studies, according to Moustakas (1994) which were taken from Van Manen's psychological perspective based on the orientation of the humanistic sciences, among others, namely (a) Emphasizing the phenomenon to be explored from the point of view of a single concept or idea. (b) Exploration of the phenomenon in groups of individuals who have experienced the phenomenon. Thus, heterogeneous groups are identified that may vary in size from 3 to 4 to 10 to 15 individuals. (c) Philosophical discussion of the basic ideas involved in phenomenological studies. This discussion explores the life experiences of individuals and how they have a subjective experience of the phenomenon as well as an objective experience of the same thing with other people. Thus, the subjective-objective perspective is rejected and, for this reason, phenomenology lies on the continuum between qualitative and quantitative research. (d) In some forms of phenomenology, the researcher "locks himself" into the study by talking about his personal experience with the phenomenon. This does not completely exclude the researcher from the study but serves to identify personal experiences with the phenomenon and partly exclude those experiences so that the researcher can focus on the experiences of the study participants. This is ideal, but readers can learn from the researcher's experience and focus only on the participants's experiences with the description. Giorgi (2009), considers that this confinement is not to forget what has been experienced but to prevent past knowledge from intervening in determining the experience. (e) Data collection procedures usually consist of interviewing people who have experienced the phenomenon. However, this is not a universal feature, because some phenomenological studies involve a variety of sources and data, such as poetry, observations, and documents. (f) Data analysis that may follow a systematic procedure that moves from a narrow unit of analysis (e.g., a major utterance) to a broader unit (e.g., a unit of meaning) and then toward a detailed description that summarizes two elements, namely, "what" has been studied. experienced by individuals and "how" they experience it (Moustakas, 1994), (g) Phenomenology ends with a description section that discusses the essence of the individual's lived experiences involving "what" they have experienced and "how" they have experienced it. The "essence" or gist is the pinnacle aspect of phenomenological studies.

\section{Development}

The Circle of Peace Foundation is an alternative place to house ex-convicts and terrorist fighters when they leave prison. Some of them got out of jail to recover and mingle with the community, but not a few of them joined the former community and relapsed into terror (bombing, terrorizing, shooting at police), etc. The terrorist community provides two supports to its members. The first support is non-material support in the form of ideology, friendship, providing radical understanding to its members through ongoing programs. The second, material support in the form of support for education expenses, employment, health expenses, etc. The two supports bind the members together, making it difficult for them to leave the network. If they leave, they have no friends, are ostracized, and even threatened. Therefore, the PCF seeks to form a new community that provides similar support, but with the content of love for peace, love for the country, tolerance, defense of friendly Islam, not anger.

The founders of the Peace Circle Foundation understand that the roots of terrorism are not singular but interrelated, so the way to address it should not be singular but should have many aspects, using different perspectives and methodologies. Like a disease, terrorism in Indonesia is currently experiencing complications that must be treated by specialists and prevention campaigns from people who have experienced this disease. This profile provides a brief overview 
to the public, agencies and institutions involved in handling the problem of terrorist extremism, which aims to provide the necessary information related to the handling of the problems carried out by the Peace Circle Foundation.

\subsection{History of the Founding of the Peace Circle Foundation}

The creation of the Peace Circle Foundation was motivated by a series of acts of terrorism in Indonesia. From 2000 to 2021 , there have been many terrorists, from suicide bombings to shootings of police officers, which are still ongoing and seem not to have been stopped. Some of the terrorists have diverse backgrounds, some are graduates of the Afghan military academy of mujahideen, Mindanao alumni, alumni of the Ambon and Poso (name of the town) conflicts, as well as from the ISIS network. Every time there is an act of terror, the perpetrators can be said to be related to one of these networks. However, not all former students are willing to continue their sporadic actions that endanger the society and the state and even contradict human values. Some of them realized that this despicable act was counterproductive and created a greater danger of disturbing the peace and noble ideals of the Indonesian nation. The founders of the Peace Circle Foundation are already remarkably familiar with global and local conflicts, among them after committing acts of terrorism who have been hunted down and arrested by the police and imprisoned for five, ten, fifteen years and some have even been sentenced to life imprisonment. depending on their level of involvement in this clandestine network. They have just realized that to solve problems one does not always have to take up arms and violence, there are still many other more promising options, such as participating in peace campaigns and creating institutions as a forum for self-affirmation to contribute to peace and prosperity in the life of the nation and the state.

\section{Membership Now}

Until now the number of members of the peace circle from former convicts is 110 people while the members who are still serving time in various Indonesian prisons are 57 people, the peace circle also provides guidance to hundreds of families of former convicts consisting of the father and mother of convicts, wives and children of convicts. This is done by the Peace Circle to break the chain of terrorism in Indonesia.

\section{The Meaning of Religious Moderation for Former Terrorist}

The data obtained were analyzed using phenomenology (Moustakas) which prioritizes the exposure of the subject in understanding, exploration, doing, and desired expectations. The flow of phenomenological exposition in Moustakas' model, first, is a description of the phenomenon (transcription) of the interview recording. Second, make an inventory of the important statements (bracketing and epoche) that are relevant to the topic. Third, classify the important statements (items) into themes or units of meaning, and leave aside those that are traversed, and fourth, construct a comprehensive description of the meaning of the subjects' experiences. However, phenomenological analysis can be carried out simultaneously. By presenting the data directly, an analysis of the subjects presented can be carried out. In conducting this research, the analysis is carried out in a flexible manner, without reducing the essence and substance of the data obtained so that it still yields conclusions in line with the objectives.

The initial entry and involvement in terrorist acts occurred when they were influenced and got a different perspective on the state of the Indonesian government. The influence is from a 
friend. These are the stories of former convicts who are shown and do not mind being named. Sequentially the former terrorist told the researchers.

\section{Discussion of the Essence of Meaning}

The Peace Circle Foundation is very helpful to ex-convicts because of their extensive knowledge and understanding of Islam and their skills. The subjects are no longer radical or angry with the government. The governmental system, in the subject's opinion, is no longer a system of thought, but the Indonesian government is trying to be fair in a pluralistic country. The PCF is very significant in moderating the Islamic understanding of ex-terrorist convicts who are coveted by convicts who have committed disassociation or been released from radical groups.

The Peace Circle Foundation is a place to repent and awaken from angry Islam to friendly Islam. The Napiter realized that the Islam he had understood so far was wrong. In Islam, there is ukhuwah, friendship, tolerance, deliberation, and justice. Therefore, killing people who are not in line is not allowed. The PCF educates the subject with programs concerning the understanding of Islam and humanity. All the subjects were happy for the presence of the Peace Circle Foundation to take care of the healing and assistance of the convicts who had carried out the disaassociation.

With the recitation of "the way of light" conducted by the Circle of Peace Foundation, a new community for ex-convicts has grown into a normal society that can be accepted by the public. In addition, ex-convicts and government officials, police, TNI and others. The Way of Light Study is a vehicle for self-awareness of violent behavior, tyranny, cruelty, and crime for innocent human beings. Through its moderation programs, the Circle of Peace Foundation creates a new atmosphere for the surrounding community or outsiders to feel at peace and stop suspecting each other. With the programs of the Peace Circle Foundation, there is no longer radicalism and narrow understanding of jihad and the intention to establish a Khilafah state in the middle of the Republic of Indonesia. The Peace Circle Foundation is a foundation that creates shade in Islam for the condemned.

\subsection{Description of the Peace Circle Foundation Educating Former Terrorist}

Based on the data collected through observation, interviews and documentation, the description of the Circle of Peace Foundation and the ways in which moderate Islam education for ex-terrorist convicts is carried out can be presented and analyzed in narrative form as follows. In the effort to foster terrorism convicts carried out by the state so far, the results have not been maximal. Not a few terrorism convicts have influence on other convicts within the Correctional Institution (where they are detained. The fight against terrorism by taking measures, law enforcement, mobilization of police, especially Denso 88 and execution of death penalty has not solved the problem of terrorism. Therefore, it is necessary to use a soft power approach, i.e., seek the deradicalization of former terrorism convicts to prevent the emergence of new terrorists later. The soft power approach that can be attempted to deal with religious radicalism is like the language of Weber's thesis "Religion with a set of personnel is the spirit to determine harmony in the sense of rejecting the emergence of new radical ideologies in the social life of people".

In this regard, Mustafa, director of the association of Islamic boarding schools in West Java, said that the ineffective steps taken so far to break the chain of terrorism have been with a militaristic approach that only prioritizes the legal process. This process only breaks the central axis but has not further investigated and optimized other approaches such as economic, social, especially religious. Therefore, there is a need to have a forum or community institution that can 
accommodate the existence of ex-terrorist convicts and their place of return by providing them with provisions in the form of training in Islamic knowledge and/or skills before associating with the community at large. This is necessary as an effort to deradicalize the religion so that the emergence of terrorists in Indonesia will be non-existent or at least reduced.

This effort has grown out of the idea of the ex-terrorist convicts, namely the creation of the Circle of Peace Foundation. The foundation is dedicated to empowering the families of ex-terrorists as well as providing a place for ex-terrorist convicts to return before interacting with the community at large. The Circle of Peace Foundation was established in the village of Tenggulun, Solokuro District, Lamongan Regency. This foundation was founded by Ali Fauzi with former terrorist convicts. This foundation is one of those dedicated to the Control Flow Integrity (CFI) with the aim to change the mindset of the families of ex-terrorist convicts and ex-terrorist convicts to a friendly and non-confrontational form of Islam and keep them away from destructive and intimidating attitudes. As chairman of the PCF, Ali Fauzi brought together several ex-combatants, such as Anis Yusuf, a former group of Osama Bin Laden, Iqbal Hussein Thoyib, a bomb plotter at the Police Headquarters, and other former terrorists. Currently, this foundation has 60 trustees throughout Indonesia.

Various programs of the Peace Circle Foundation, namely, holding regular recitations, workshops on strengthening the economic skills of young people through journalism training. The foundation also organizes training courses for the children of ex-convicts through their participation. As an advisor to the Circle of Peace Foundation, Anas Yusuf toured from one prison to another. They (YLP administrators) invited the existing ex-convicts to dialogue. The National Agency for Combating Terrorism (BNPT) awards the administration and participates and supports the deradicalization program implemented by this foundation. These include efforts to establish the construction of places of worship in the form of mosques and Al-Quran education parks. Komjen Pol Suhardi Alius, as head of BNPT RI, stated at the time that the construction of Islamic Boarding School Plus and the renovation of Baitul Muttaqin Mosque would become a new tower. In addition, Suhardi added, TPA Plus can educate the new generation/successful to become useful children for the nation and always maintain the integrity of the Unitary State of the Republic of Indonesia (NKRI).

Based on the above phenomenon, the existence of deradicalization efforts carried out by the Peace Circle Foundation for ex-terrorists, it is necessary to know the communication strategy carried out by this foundation as a soft power approach model in the form of special coaching to seminars, talk shows, workshops, and training activities conducted by PCA. Communication strategy is a guide from planning and management of communication to achieve a goal. Therefore, the author is interested in conducting research that focuses on the communication strategy carried out by the Peace Circle Foundation as an effort to deradicalize ex-terrorist convicts. Strategies and Methods of the Circle of Peace Foundation. Strategy can be defined as a process of determining the way top leaders focus on the long-term goals of the organization, accompanied by the preparation of a method or effort on how to achieve these goals. This is stated in a book entitled Strategic Management in Action, Stephanie K. Marrus. Several things related to the strategy carried out by the Peace Circle Foundation can be described in the following section.

\subsection{Communicator or Educator}

Communicators are the spearhead of successful communication. A communicator is not unlike a leader in conducting an event, as well as an institution to become an institution that is able 
to provide maximum service to those it fosters. The Circle of Peace Foundation selects special people in nurturing former terrorists. Many people who have been in contact with cases of acts of terrorism participate. Ali Fauzi himself is a former Filipino fighter.

In addition to internal communicators, the foundation also invites external communicators, such as the police, TNI, lecturers, and academics, to bring new ideas and developments on issues for ex-convicts in the form of lectures, training, and workshops. As Mahendra (Amrozi's son) said, at the Peace Circle Foundation, it is not enough to manage it internally, but also to manage it externally. One of the external management is that we have introduced various sources from outside. Our goal (PCF administrators) is that they master writing or what we know as journalistic activities.

In conducting the training of former terrorists, a communicator or educator really knows his or her world as one who catches a thief. He must know the ins and outs of the world of theft. The same is true with the nurturing of ex-terrorist convicts. This case of terrorism is said to be a matter of "sacred ideology" which is completely different from other cases such as those convicted of drug trafficking, corruption, or rape to sexual harassment cases. Therefore, the presence of the Peace Circle Foundation is something very appropriate because the founding president has experienced how he was brainwashed and then radicalized to be willing to go to conflict zones like Afghanistan, Palestine, and others. Then, in the end, he realized and found his identity that all this time his actions (radical behavior) were the wrong path and he could not continue. It was from this experience that Ali Fauzi and the ex-fighters of Poso and Ambon took the initiative to bring together ex-terrorist convicts under the auspices of the Peace Circle Foundation. It is not enough, they are ex-terrorist convicts after their release from prison, as they have lost their family, their relatives, and above all their work, which will later be the livelihood of their lives. They have to be given education, training, journalism training and introduced to external sources of the Circle of Peace Foundation and also to the police security of the Lamongan Regency.

\subsection{Setting Goals}

The handling of the problem of terrorism is very different from the problems of other convict cases such as drug problems, sexual harassment problems, and corruption problems. The problem faced by ex-terrorist convicts relates to the "sacred ideology" that must be fought for and defended. They are willing to die defending and fighting for religion, they think what they have done is because of li i'lai kalimatullah, namely exalting the words of Allah. Therefore, these exconvicts need to be handled specifically. In dealing with these ex-terrorist, the most complicated and difficult part is how to change the mindset that they have considered as ideology, so that they are aware that their pattern of steps has not been correct. This foundation educates and fosters, and provides skills training and they mingle with the community and assist community activities such as mutual cooperation in building bridges, houses, cleaning the environment and others.

The target of coaching ex-terrorist convicts carried out by the Peace Circle Foundation is to change the mindset of ex-terrorist convicts from an angry or extreme ideology to a friendly or moderate ideology, from a destructive to a constructive ideology, from those who move away from the order of life in the Unitary State of the Republic of Indonesia back to the motherland. And one of the reasons why they belong to a terrorist group is none other than because they are brainwashed into becoming hard-line followers of Islam. An ex-terrorist convict tells the story of how questions were put to him and then he turned radical. One of them is from several questions that make him unintentionally seem to be led to hardline Islam. Nasyir Abbaas, one of the former 
terrorist convicts who came to his senses and returned to the motherland's lap, revealed that he had become a terrorist at the age of 18. Initially he joined the first war in Afghanistan and there he was taught how to hold a weapon to assemble a bomb. At first he met with Abu Bakr Ba'asyir. From this encounter, it was as if I had become a cow whose nose was poked until I was helpless, as if a robot moving with a remote control. I did not know and was under conscious at that time whether my path was right or wrong.

The awareness is now clear from the former terrorist who re-recognize the Unitary State of the Republic of Indonesia, they join the terrorist group because they are not aware that they have been brainwashed at that time. Now they are aware and mingle with the wider community and become ordinary people. When he was asked about the glory of the Prophet Muhammad compared to the President of the Republic of Indonesia, the 1945 Constitution compared to the sanctity of the Koran is something that really shouldn't be compared. But questions like that can lead them to be fundamentalists and radicals. Radical views and behavior are caused by the paradigm of thinking, so the deradicalization programs carried out by the Lingkar Peace Foundation. This foundation aims and aims to make them aware that the actions they have taken so far are not right. Their impression is that the police are fit, the police are creatures that must be destroyed. This kind of thinking was experienced by Ali Fauzi himself before then after that he changed all of this mindset. At the next target after they changed their mindset and they continued to be nurtured and maintained. Not only that, the hope for the future is how they (former terrorist convicts) after being fostered and brainwashed at the Peace Circle Foundation, they return to their villages, communities, and their respective homes and have been accepted and the community gives a positive impression on them without receiving ridicule from them. their families and communities. They began to realize that all this time what they were doing was wrong, so it was rare for them to always provide services to them (ex-terrorist convicts) with various educational activities such as journalism training aimed at training them to write, as well as training in baking cakes and raising animals. These two programs are intended so that after they are at PCF, they can live independently so that they can support their lives later after they return to their respective homes. They (the former terrorist convicts) have been in prison for several years. There are eight, ten, up to 15 years. After they leave, their economic life starts to zero while most of them bear the burden of the family. So the education carried out by PCF becomes meaningful. The trainings and skills provided are sufficient for their capital and provision when they return to the community.

\subsection{Designing Messages}

The Peace Circle Foundation presents successful figures as well as figures who are truly pro and support the existence of the establishment of the Peace Circle Foundation. Ali Fauzi as the founder always seeks support from many groups, especially related parties including the police and BNPT for the sustainability of the Foundation. While inside he gives peace motivations to exterrorist convicts. Ali told them that he had the same views and thoughts as them, namely ending life as a terrorist and returning to a normal life. Ali Fauzi always talks about his experiences as a terrorist and how he has changed step by step. In this way, this informative-educative message was received by other former terrorist convicts who were in the Peace Circle Foundation. In a book written by Hafied Cangara (2013) with the title Communication Planning and Strategy, it is stated that there are three types of messages, namely messages that are informative, persuasive, and educative. The nature of information messages is to explain something to others, this type of information message is divided into two, namely actual information and general information. 
Furthermore, messages that are persuasive in nature have the proposition that there are results received by the source for the message he conveys to the communicant, in the sense of changes in the communicant's self which becomes his priority scale. The third is messages that are educative, so the emphasis of this type of message model is on the cognitive, affective, and psychomotor elements.

In the message delivery model, it is not enough just to understand or know (cognitive) but how the message can be understood so that it becomes a misfortune in a person (effective) then the message received is said to be successful when the message is practiced at the level of real life (psychomotor). The messages conveyed by the Peace Circle Foundation through the management of the Peace Circle Foundation from the delivery of figures from outside already contain the three types of values above. Regarding the type of informative message, Ali Fauzi, the founder assisted by combatants, often informs the congregation in the Peace Circle Foundation to always maintain the peace, tranquility and integrity of the Unitary Republic of Indonesia and reject hoax news. Messages from the Circle of Peace Foundation are included in the educational category. This is evidenced by the holding of mentoring, scientific seminars, training related to animal husbandry, to the making of cakes that are deliberately given to ex-terrorist.

In compiling this message, it is based on the basic assumptions of the rhetorical theory reported by Aristotle, that there are two basic assumptions of the rhetorical theory. First, so that the message that will be assembled can be accepted by the listeners or participants, it is by looking at the context of the message that will be presented. Second, by using rhetorical tools, namely Ethos, Logos and Pathos. Based on Ali Fauzi's observations, he has tried to compose humanist messages in providing direction and guidance to ex-terrorist convicts. The content and context of the messages conveyed to former terrorist convicts who are at the Lingkar Peace Foundation do require caution, foresight and patience considering their condition is still semi-sensitive and fanatical.

\section{Choosing the Right Media}

The message should be conveyed through the mass media to target a wider community. The media used in this coaching uses social media such as news written on the website to YouTube. This is done so that the world knows how the efforts of the Circle of Peace Foundation really exist and are implemented. With efforts to clean up and restore the stigma for Tenggulun village as a black village, a den of terrorists, it was eroded by the establishment of the Peace Circle Foundation in this place. Now we can see the history of Tenggulun's journey, which was once a hotbed of radicals and terror, now a center for deradicalization activities.

According to data presented by IDN TIMES, in 1986 Ali Gufron, Amrozi's older brother, went to war in Afghanistan for approximately six years. After that he returned to his native village, Tenggulun and brought radical ideas. In 1992 the Al Islam Islamic Boarding School was founded with radical ideologies. This Islamic boarding school does not allow the existence of the Pancasila ideology and prohibits the activities of the Indonesian independence ceremony. In 2002, the Bali Bombing 1 incident occurred which killed approximately 202 people. In the aftermath of the incident, three people: Ali Imron, Amrozi and Ali Gufron were arrested by Densus 88. Four years later, in 2008, Amrozi and Ali Gufron were executed while Ali Imron was imprisoned for life. In 2012 Ali Fauzi was determined to establish a community which was later given the name Circle of Peace. Islamic Boarding School, Al Islam began to fade from the ideology that was previously radical. In 2016 the Peace Circle Foundation was officially established in Tenggulun, an institution engaged in handling 
former terrorist and has a vision and mission of embracing those exposed to radical ideologies back to inclusive and moderate ideologies.

In 2018, Tenggulun became popular and worldwide, if it used to be famous for its bad symbols and image as a nesting village for terrorists, and a black village, it turned into a deradicalization center village. The Dutch government envoy came to Tenggulun, they wanted to learn a lot from Indonesia, especially the Peace Circle Foundation. The Dutch want to witness firsthand how they (people who were previously exposed to radical ideas) have now turned into a group of people who echo the values of humanist and moderate Islam. A state coveted by the nation and state, especially the Tenggulun people.

The condition of Tenggulun Village above cannot be separated from the selection of social media used by the Peace Circle Foundation in promoting and echoing the values of world peace. Several foreign countries, such as Australia, Japan, America, Armenia and others know how the deradicalization carried out by the Peace Circle Foundation has never been separated from the role of social media in informing the deradicalization activities carried out in this place. The foundation is often visited by journalists to cover several activities, including the making of a short film made by BBC London at the foundation. This foundation cooperates with domestic and foreign agencies. Then the news was spread on social media such as through Youtube media to online news such as detik.com. Some examples of how to use this media can be seen on several online news websites such as Detik, Tribunnews, Beritasatu, Radar, and others.

\section{Conclusion}

The Peace Circle Foundation is interpreted and congratulated by the ex-terrorist convicts as a place of refuge and hope for spiritual and non-spiritual support for their future life. The vision and understanding of Islam provided to them is very broad and deep, and the skills and training are functional. As a result, the subject is no longer radical or confrontational with the government. The system of government that was once considered the system of the cursed has now changed to respect the Indonesian government. PCF is very significant in moderating the Islamic understanding of ex-terrorist convicts who are coveted by the convicts who have disassociated or have been released from the radical groups.

The Circle of Peace Foundation is a place to find new hope for life, repent and awaken from angry Islam to friendly Islam. Inside there is an imam who encourages the spirit to migrate from radical to moderate thinking, and the former terrorists realized that the Islam they had understood so far was wrong. All the subjects were glad of the presence of the Circle of Peace Foundation to manage the healing and assistance of the ex-convicts who had carried out disassociation. The Peace Circle Foundation is a foundation founded by Ali Fauzi with former terrorists. This foundation is one of those dedicated to the integrity of control flows with the aim of changing the mentality of the families of ex-convicts and ex-terrorists towards a friendly and non-confrontational form of Islam and away from destructive and intimidating attitudes.

The communication strategy of the Peace Circle Foundation is in line with communication theories, i.e., selection and choice of reliable and really competent communicators in their fields, such as the president of the Peace Circle Foundation, Ali Fauzi, who has dark history and knows the psychology of ex-terrorist convicts. Moreover, determining the goal is to change the radical mentality to a humanistic mentality, the angry mentality to a friendly mentality, compiling peace messages to build the country to create the face of world peace. That is not enough, it is necessary for the media to report that Tenggulun, once a den of terrorists, has now become a village of deradicalization centers. 


\section{REFERENCES}

Arifin, S., \& Hasnan, B. (2013). Deradicalization of the Ideology of Radical Transnational Islamic Movements. Harmoni, Multicultural Journal, 12(3), 19-36

Bertens, K. (2001). Summary of the History of Philosophy. Kanisius.

Budisulsilo, A. (2001). Menggugat IMF. Gramedia.

Creswell, J. W., \& Poth, C. (1998). Qualitative Inquiry and Research Design. Choosing Among Five Approaches. Sage Publications.

Creswell, J. W. (2018). Research Design: Qualitatave, Quantitative and Mixed Methods Approaches.

Elshahed, E. (1992). What is the Challenge of Contemporary Islamic Fundamental? In H. Kung \& J. Moltmann (eds.) Fundamnetalism as a Ecumenica. London.

Guba, E. (1978). Toward a Methodology of Naturalistic Inquiry in Educational Evaluation. University of California, Los Angeles, Center for the Study of Evaluation.

Husaini, A. (2001). Osama Versus American Jihad. Gema Insani .

Jainuri, A. (2006). Terrorism in contemporary Islamic discourse: Ideological roots and demands for Action. Professor Inauguration Speech. IAIN Sunan Ampel.

Jainuri, A. (2006). Promise of heaven in the midst of poverty. Jawa Pos.

Jainuri, D. (2003).Terrorism @ Religious Fundamentalism. Bayu Media.

Moustakas, C. (1994). Phenomenological Research Methods. Sage.

Muslih, M. (2005). Philosophy of Science: A Study of Basic Assumptions and Paradigms and Frameworks of Scientific Theories. Belukar.

Ritzer, G. (2003). Sociology of Science with a Dual Paradigm. Rajawali Press.

Tehranian, M. (1993). Fundamentalists Impact on Education and the Media: An Overview. University of Chicago Press.

Tibi, Bassam. (1993). The Worldview of Sunni Arab Fundamentalists: Attitudes toward Modern Science and Technology'. In M. Martin and S. Appleby (eds), Fundamentalisms and Society. (pp. 73-102) Chicago University Press

Wardlaw, G. (1989). Political Terrorism: Theory, Tactics and Counter-Measures. Cambridge University Press

\section{AUTHORS}

Ishomuddin Umm. Lecturer at the University of Muhammadiyah Malang Indonesia, and senior researcher. His field is the sociology of Islamic society. His field is the sociology of Islamic society. He was a visiting professor at the University of Malaya, Malaysia and AICHI in Japan.

Ali Fauzi. Candidate for a doctorate in sociology. Socio-cultural and political observer.

Syamsul Arifin. Lecturer at the University of Muhammadiyah Malang Indonesia, and Senior researcher. His field is the sociology of Religion. He was a visiting professor at the Oslo.

Abdul Haris. Lecturer at the University of Muhammadiyah Malang Indonesia experience. 